\title{
PURIFICATION AND OPTIMIZATION OF CONDITIONS FOR DNA POLYMERASE ISOLATED FROM THERMOPHILE BACTERIA BACILLUS CALDOLYTICUS
}

\author{
Zoran T. Popovski ${ }^{1 *}$, Tome Nestorovski ${ }^{1}$, Milica Svetozarević ${ }^{2}$, \\ Elizabeta Miskoska-Milevska ${ }^{1}$ \\ ${ }^{1}$ Department of Biochemistry and Genetic Engineering, Faculty of Agricultural Sciences and Food, \\ Ss. Cyril and Methodius University, Skopje, Republic of Macedonia \\ ${ }^{2}$ Laboratory for Protein and DNA Technology, Faculty of Technology and Metallurgy, \\ Ss. Cyril and Methodius University, Skopje, Republic of Macedonia \\ zoran_popovski@yahoo.com
}

\begin{abstract}
Thermophilic bacteria Bacillus caldolyticus isolated from the hot spring in Bansko, Republic of Macedonia, were used for the isolation of DNA polymerase. Bacterial cells were disrupted by sonication and the first step in the purification of DNA polymerase was $40 \%$ ammonium sulfate precipitation. This was followed by chromatographic procedures on Sephadex G-50, DE-52 and CM-52 cellulose. DNA polymerase activity was analyzed at each step of purification using the incorporation of ${ }^{3} \mathrm{H}$ dATP in activated calf thymus DNA. The purity of the DNA polymerase was analyzed on SDS PAGE. Optimal conditions of activity were determined for temperature, $\mathrm{pH}, \mathrm{dNTP}$ and $\mathrm{Mg}^{++}$concentration. In addition, the effect of ethanol and EDTA as possible inhibitors of polymerase activity was also analyzed. The optimal temperature of DNA polymerase was $66^{\circ} \mathrm{C}$; the optimal $\mathrm{pH}$ was 7.2 , optimal $\mathrm{MgCl}_{2}$ concentration was $2.5 \mathrm{mM}$, and the optimal substrate concentration was $2.5 \times 10^{-6} \mathrm{M}$ dNTP. The inhibitory effect of EDTA and ethanol on DNA polymerase was above $10 \mathrm{mM}$ and $10 \%$, respectively.
\end{abstract}

Keywords: Bacillus caldolyticus; DNA polymerase; purification; optimization; inhibitors

\section{ПРОЧИСТУВАњЕ И ОПТИМИЗИРАЫЕ НА УСЛОВИТЕ ЗА ДНК-ПОЛИМЕРАЗА ИЗОЛИРАНА ОД ТЕРМОФИЛНАТА БАКТЕРИЈА ВАCILLUS CALDOLYTICUS}

Термофилната бактерија Bacillus caldolyticus изолирана од термалниот извор во Банско, Република Македонија, беше користена за изолација на ДНК-полимераза. Бактериските клетки се лизирани со ултразвук и првиот чекор во прочистувањето на ДНК-полимеразата беше исталожување со $40 \%$ амониум сулфат. Потоа следуваа хроматографски процедури на Sephadex G50, DE-52 и CM-52 целулоза. Активноста на ДНК-полимеразата беше анализирана во секој степен на прочистувањето со инкорпорација на ${ }^{3} \mathrm{H}$ dATP во активирана ДНК од телешки тимус. Чистотата на ДНК-полимеразата беше анализирана со користење на SDS PAGE. Оптималните услови за активноста беа одредени за температура, $\mathrm{pH}, \mathrm{dNTP}$ и $\mathrm{Mg}^{++}$. Дополнително беа анализирни ефектите на етанолот и EDTA како можни инхибитори на ДНК-полимеразната активност. Оптималната температура за оваа ДНК-полимераза е $66{ }^{\circ} \mathrm{C}$, оптималната $\mathrm{pH}$ е 7.2 , оптималната концентрација на $\mathrm{MgCl}_{2}$ е $2.5 \mathrm{mM}$, додека оптималната концентрација на dNTP е $2.5 \times$ $10^{-6}$ M. EDTA покажува инхибиторен ефект врз ДНК-полимеразата во концентрација над $10 \mathrm{mM}$, додека етанолот во концентрација над $10 \%$.

Клучни зборови: Bacillus caldolyticus; ДНК-полимераза; прочистување; оптимизација; инхибитори 


\section{INTRODUCTION}

DNA polymerases are ubiquitous enzymes present in all prokaryotic and eukaryotic cells [1]. They have a crucial role in DNA replication, repair and recombination processes $[2,3]$. Two unclear phenomena in biology, cell proliferation and the impossibility of nerve cell division, are closely related to DNA polymerase activity [4]. Interest in thermophilic bacteria has been focused on the discovery of new strains, which can be used as a source for the production of thermostable enzymes [1]. The wide use of polymerase chain reaction (PCR) has resulted in intensive investigations of thermostable DNA polymerases [5]. The main feature of the DNA polymerases that makes them suitable for PCR purposes is their resistance to denaturation after exposure to the melting temperature step of approximately $95{ }^{\circ} \mathrm{C}$. Several thermostable DNA polymerases have been isolated from Thermus aquaticus, Bacillus stearothermophilus, Sulfolobus acidocaldarius, Pyrococcus furiosus, and Thermotoga litoralis [6-10] using mostly chromatographic procedures. Currently in PCR, the most frequently used polymerases are Taq DNA polymerase, Vent DNA polymerase and Pfu DNA polymerase. It is well known that the polymerase chain reaction (PCR) is susceptible to inhibitors and there are methods described for assessing inhibition using spiked alien molecules of various types [11]. The presence of inhibitors has the potential to increase error, reduce assay resolution, and produce false results in both quantitative and qualitative PCR assays [12]. The thermophilic bacteria Bacillus caldolyticus, was discovered in a hot spring in Bansko, Republic of Macedonia [13]. The aim of this study was to isolate thermophilic bacteria from hot springs at Bansko, to purify the DNA polymerase from such a strain, to optimize the conditions for its activity and to estimate the inhibitory effect of some compounds used in PCR.

\section{EXPERIMENTAL SECTION}

The samples for isolating of thermophilic bacterial strain were taken from the hot spring at Bansko, Republic of Macedonia, where the water temperature is $72{ }^{\circ} \mathrm{C}$. The characterized bacterial strain [13] was cultivated in Luria-Bertani (LB) and bacterial biomass was obtained by continuous cultivation with a flow rate of $0.2 \mathrm{~V} / \mathrm{h}$ in a New Brunswick $^{\mathrm{TM}}$ BioFlo ${ }^{\circledR} 115$ System fermenter with a working volume of 0.350 liters, using special thermal devices at the maximum available temperature of $66^{\circ} \mathrm{C}$. The $1 \mathrm{~g}$ bacterial cells were re-suspended in a $2 \mathrm{ml}$ basic buffer ( $25 \mathrm{mM}$ TRIS buffer, $\mathrm{pH} 8.3$, $1 \mathrm{mM}$ EDTA and 5\% glycerol). Cell lysis was achieved by sonication using a MICROSON XL homogenizer (Pere IV 160, Barcelona, 08005 Spain). DNA polymerase activity was determined via incorporation of ${ }^{3} \mathrm{H}$ dATP in activated calf thymus DNA [14]. The incubation mixture contained: $5 \mu \mathrm{l} 10 \times$ PCR buffer $(100 \mathrm{mM}$ Trizma-HCl $\mathrm{pH} 8.3$ at $\left.25{ }^{\circ} \mathrm{C} ; 500 \mathrm{mM} \mathrm{KCl}\right) ; 5 \mu \mathrm{l} 25 \mathrm{mM}$ $\mathrm{MgCl}_{2} ; 5 \mu \mathrm{l} 2.5 \mathrm{mM}$ dNTP (dATP, dTTP, dGTP, dCTP); $2 \mu$ l activated calf thymus DNA with a concentration of $2 \mu \mathrm{g} / \mu \mathrm{l} ; 0.2 \mu \mathrm{l}{ }^{3} \mathrm{H}$ dATP with a radioactivity of $0.2 \mu \mathrm{Ci} ; 5 \mu \mathrm{l}$ bacterial lysate and deionized $\mathrm{H}_{2} \mathrm{O}$ up to final volume of $50 \mu \mathrm{l}$. The reaction mixture was incubated at a previously determined optimal bacterial temperature $\left(66^{\circ} \mathrm{C}\right)$ for 30 minutes in a thermal cycler; DNA polymerization was stopped by chilling at $-20^{\circ} \mathrm{C}$. The amount of reaction mixture was divided into two aliquots of $20 \mu \mathrm{l}$ and loaded on two pieces of filter paper (Whatman-3 $1 \times 1 \mathrm{~cm}$ ). The first one was used as a control for the total amount of radioactivity, while the second was washed with $10 \%$ trichloroacetic acid which contained $0.1 \mathrm{M}$ Na pyrophosphate for $1 \mathrm{~h}, 5 \%$ trichloroacetic acid for $15 \mathrm{~min}$, a mixture of ether and ethanol in ratio $1: 1$ for $30 \mathrm{~min}$ and ether for $15 \mathrm{~min}$. After washing, the filters were dried and immersed in $2.5 \mathrm{ml}$ of scintillation mixture which was prepared using 1 liter Triton X-100, 1 liter toluene, 8 g 2.5 diphenyloxazole (PPO) and $0.4 \mathrm{~g} 1.4$ bis[5-phenyl-2-oxazolybenzene] (POPOP). The radioactivity was measured on a liquid scintillation $\beta$-counter. The unwashed filter was used as a total radioactivity (total amount of ${ }^{3} \mathrm{H}$ dATP) while the washed filter was used as the amount of incorporated ${ }^{3} \mathrm{H}$ dATP. As a positive control, $1 \mathrm{U}$ of Taq DNA polymerase supplied from PROMEGA (Madison, WI, USA) was used, and a reaction mixture without enzyme was used as a negative control. One unit of DNA polymerase is defined as the amount of enzyme catalyzing the incorporation of $1 \mathrm{nmol}$ of ${ }^{3} \mathrm{H}$ dATP in acid-insoluble product for $30 \mathrm{~min}$ at an optimal bacterial temperature of 66 ${ }^{\circ} \mathrm{C}$. Purification of DNA polymerase was done using a few phases. The bacterial lysate obtained by sonication was centrifuged at $12,950 \mathrm{~g}$ for 30 min at $4{ }^{\circ} \mathrm{C}$ and the precipitate of cell debris was discarded. In the supernatant, protein precipitation was performed using 30 to $60 \%$ saturation with ammonia sulfate. The precipitate with the enzyme activity was re-suspended in the buffer which contained $25 \mathrm{mM}$ TRIS-HCl pH 8.5, $1 \mathrm{mM}$ EDTA and $5 \%$ glycerol (basic buffer) and dialyzed in the 
same buffer in order to eliminate residues of ammonium sulfate and other small molecules. The dialysis was performed using a nitrocellulose membrane with $12 \mathrm{kD}$ cutoff in dialysate/buffer ratio $1 / 100$ at $4{ }^{\circ} \mathrm{C}$. The dialysate obtained was filtered through an LKB column $(100 \times 3 \mathrm{~cm})$ using Sephadex G-50. Determination of proteins was performed spectrophotometrically at $280 \mathrm{~nm}$. The fraction with DNA polymerase activity was lyophilized, dialyzed in the basic buffer and loaded onto the LKB column $(30 \times 1.5 \mathrm{~cm})$ with anion exchange resin DE- 52 cellulose equilibrated with the basic buffer at $\mathrm{pH}$ 8.5. The fractions were collected and the fraction with the DNA polymerase activity was lyophilized and dialyzed in the basic buffer. The new dialysate was loaded on the LKB column $(20 \times 1 \mathrm{~cm})$ with the cation exchange resin CM-52 cellulose. The fraction with DNA polymerase activity was dialyzed in a buffer containing: $0.005 \mathrm{M}$ TRIS, $0.05 \mathrm{M} \mathrm{KCl}, 0.1 \mathrm{mM}$ EDTA, $1 \mathrm{mM}$ dithiothretiol (DTT), $0.5 \mathrm{mM}$ phenyl methyl sulfonyl fluoride (PMSF) and 50\% glycerol (storage buffer) and stored at $-20{ }^{\circ} \mathrm{C}$. The purity of an enzyme extract was checked using SDS-PAGE. Optimal conditions for DNA polymerase were determined using the same assay for DNA polymerase activity by incorporation of ${ }^{3} \mathrm{H}$ dATP in activated calf thymus DNA in different conditions. The incubation mixture contained basic buffer, $\mathrm{MgCl}_{2}$ in different concentrations, dNTPs at different concentrations, $4 \mu \mathrm{g}$ activated calf thymus DNA, $0.2 \mu \mathrm{Ci}^{3} \mathrm{H}$ dATP and $5 \mu \mathrm{l}$ bacterial lysate adjusted to $1 \mathrm{U} / \mu \mathrm{l}$ in a final volume of $50 \mu \mathrm{l}$. The reaction mixture was incubated at the different temperatures for $30 \mathrm{~min}$. in a thermal cycler. Polymerization of DNA was stopped by chilling at $-20{ }^{\circ} \mathrm{C}$ and the polymerase activity was determined by a previously described procedure. The optimal concentration of substrate was evaluated by changing the concentration of dNTPs, as substrate molecules, from $0.05 \mathrm{mM}$ to $0.5 \mathrm{mM}$ in $0.05 \mathrm{mM}$ increments. The $\mathrm{pH}$ optimum of the polymerase activity was determined by performing the reaction between $\mathrm{pH} 6$ and 9 in $0.3 \mathrm{pH}$ unit increments. The temperature optimum was estimated by changing the temperatures between $60{ }^{\circ} \mathrm{C}$ and $90{ }^{\circ} \mathrm{C}$ in $3{ }^{\circ} \mathrm{C}$ increments. The $\mathrm{Mg}^{++}$was analyzed as a common DNA polymerase activator by evaluating polymerase activity at different $\mathrm{MgCl}_{2}$ concentrations between 0 and $10 \mathrm{mM}$. The inhibitory effects of EDTA and ethanol on the polymerase activity were analyzed between 0 and 25 $\mathrm{mM}$ of EDTA in $2.5 \mathrm{mM}$ increments and between 0 and $20 \%$ of ethanol in $2 \%$ increments.

\section{RESULTS AND DISCUSSION}

In one liter of Luria-Bertani medium, $14.4 \mathrm{~g}$ bacterial biomass was obtained by continuous cultivation. The lysis of $5 \mathrm{~g}$ of bacterial cells was achieved using a sonicator for $5 \mathrm{~min}$ at $10 \mathrm{~W}$. The best ratio between the protein content and enzyme activity was gained with $40 \%$ ammonia sulfate. The precipitate was dialyzed in basic buffer and the purification procedure continued with gel filtration on Sephadex G-50. The fractions were separated with isocratic elution using the basic buffer containing additionally $0.05 \mathrm{M} \mathrm{NaCl}$ and collected with a flow rate of $30 \mathrm{ml} / \mathrm{h}$. (Graph 1a).

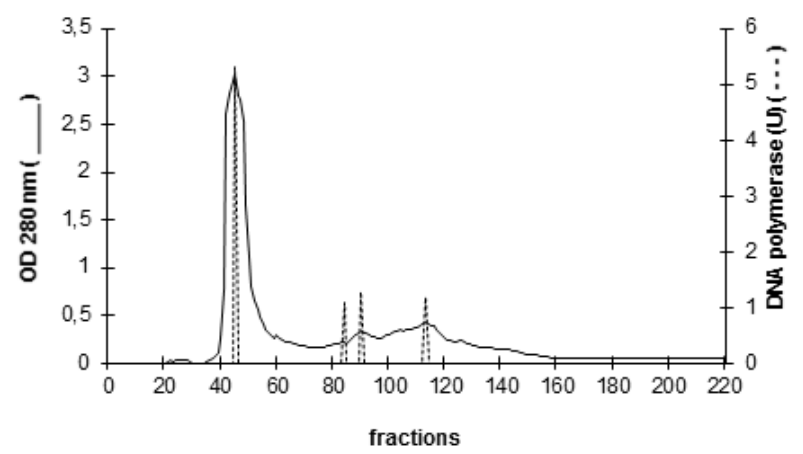

a)

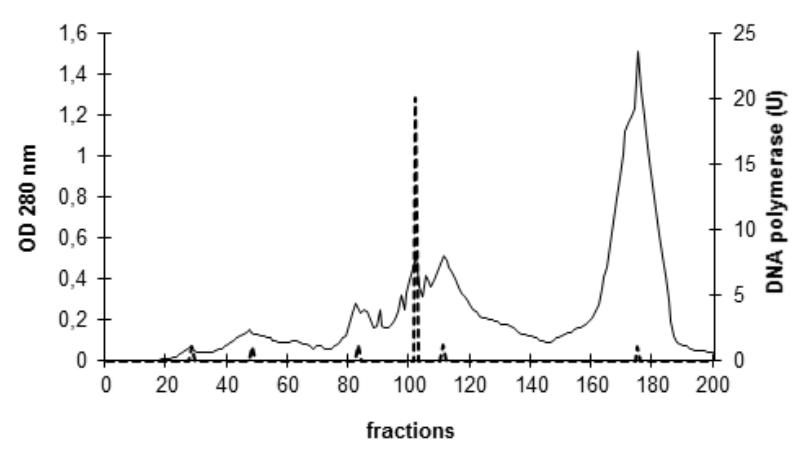

b)

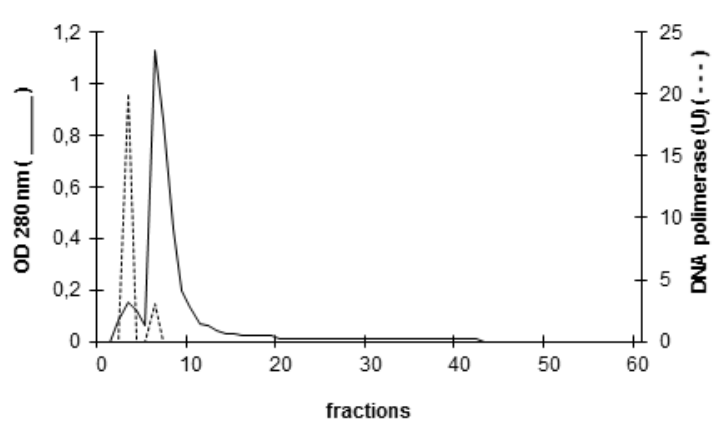

c)

Graph 1. Purification of DNA polymerase from Bacillus caldolyticus. a) Gel filtration on Sephadex G-50.

b) Anion exchange chromatography on DE-52 cellulose.

c) Cation exchange chromatography on CM-52 cellulose. 
The third phase in the purification of DNA polymerase was performed using anion exchange chromatography on DE-52 cellulose. The elution of the proteins was done using double gradient of 0 to $1 \mathrm{M} \mathrm{NaCl}$ molarity and 8.5 to $7.5 \mathrm{pH}$ gradients with a flow rate of $15 \mathrm{ml} / \mathrm{h}$ (Graph $1 \mathrm{~b})$. The final step in the purification of DNA polymerase from Bacillus caldolyticus was cation exchange chromatography on CM-52 cellulose with a $\mathrm{pH}$ gradient from 7 to 8 using the basic buffer with a flow rate of $10 \mathrm{ml} / \mathrm{h}$ (Graph 1c).

The gel filtration was not as effective because a low amount of proteins without polymerase activity (after $60^{\text {th }}$ fractions) were eliminated from further purification procedures. The most important phase in the purification of DNA polymerase from Bacillus caldolyticus was anion exchange chromatography on DE-52 cellulose. During this step, a small protein fraction with polymerase activity appears in around the $100^{\text {th }}$ fraction, which was used for the last step of purification, where column chromatography was performed using CM52 cellulose. In this phase, the peak with polymerase activity appeared in the first 5 fractions.

The determination of the molecular weight and the purity of isolated DNA polymerase were performed by SDS-PAGE. The electropherogram in Figure 1 showed that the molecular weight of DNA polymerase was close to the molecular weight of bovine serum albumin $(67 \mathrm{kDa})$.
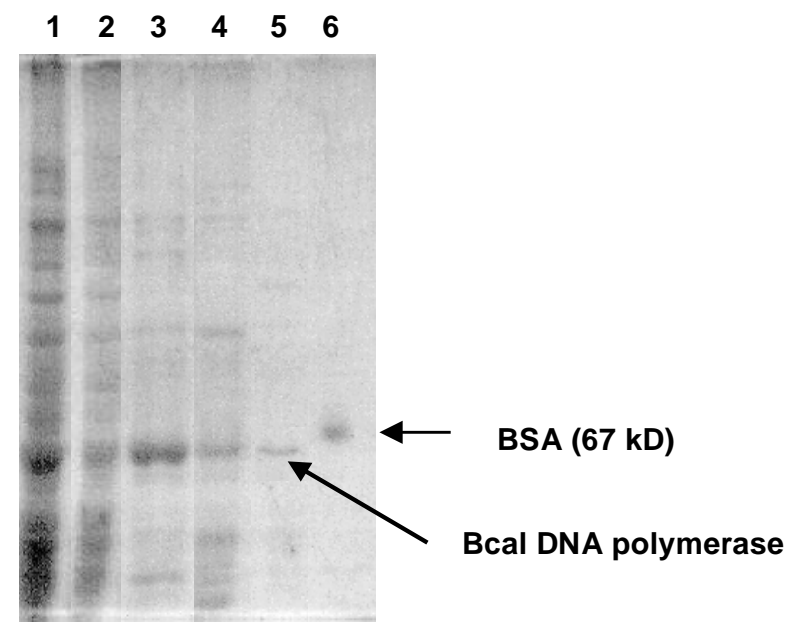

Figure 1. Analysis of the purity and the molecular weight of Bcal DNA polymerase with SDS-PAGE. 1) Bacterial lysate; 2) fraction with DNA polymerase activity obtained with $40 \%$ ammonium sulfate precipitation, 3) fraction with DNA polymerase activity obtained after gel filtration, 4) fraction with DNA polymerase activity obtained after anion exchange chromatography, 5) fraction of DNA polymerase after cation exchange chromatography, 6) Bovine serum albumin (67 kD).

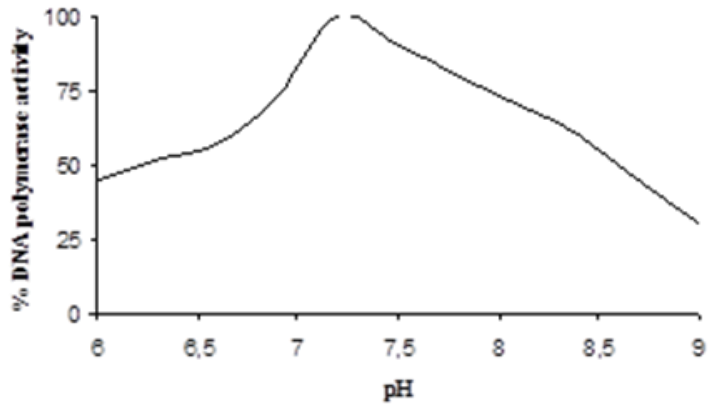

a)

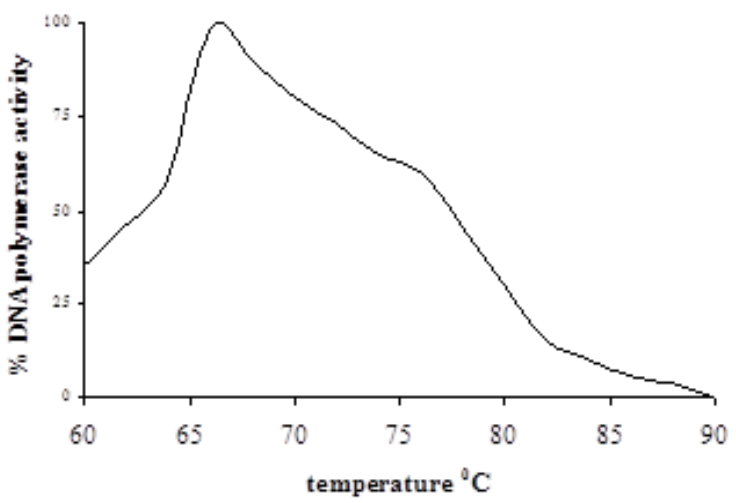

b)

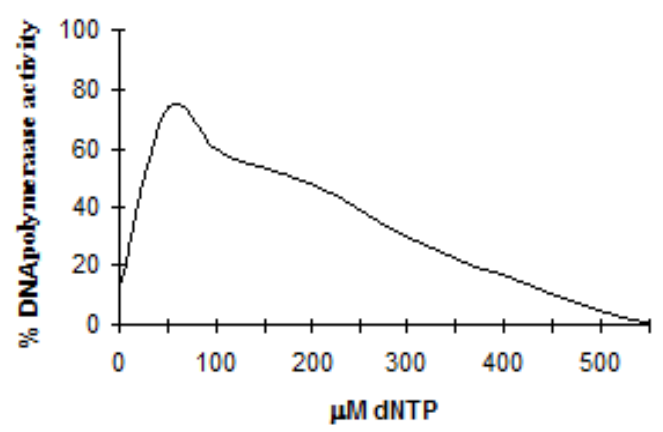

c)

Graph 2. DNA polymerase activity from Bacillus caldolyticus at different conditions. a) $\mathrm{pH}$; b) temperature; c) substrate concentrations.

The purified enzyme extract was further analyzed in order to determine the optimal conditions for its activity.

The influence of $\mathrm{pH}$ and temperature on the incorporation of dNTPs into the nascent DNA was tested. Results showed that the $\mathrm{pH}$ optimum for this polymerase is 7.2 (Graph 2a), while the optimal temperature was $66{ }^{\circ} \mathrm{C}$ (Graph 2b). The optimal concentration of dNTPs as substrate molecules were found to be $50 \mu \mathrm{M}$ (Graph 2c).

The thermal stability of DNA polymerase is the most important feature to be used in PCR reactions and this DNA polymerase along with its extensive and elevated activity between $60{ }^{\circ} \mathrm{C}$ and 70 
${ }^{\circ} \mathrm{C}$ makes it a good contender for biotechnological use, but not for PCR. The optimal temperature for B. stearothermophilus DNA polymerase was 60 $65^{\circ} \mathrm{C}$, whereas the enzymes from B. caldotenax and B. caldovelox showed the highest incorporation rate at $65-70{ }^{\circ} \mathrm{C}$. The activities were reduced significantly at higher temperatures and the enzymes were inactivated at $80{ }^{\circ} \mathrm{C}$ (B. stearothermophilus) and 85 ${ }^{\circ} \mathrm{C}$ (B. caldotenax and B. caldovelox). The enzymes from other Bacillus species showed an optimal concentration of dNTP of $85 \pm 10 \mu \mathrm{M}$, and from Thermus thermophilus of $115 \mu \mathrm{M}$ [16].

Magnesium was tested as an activator for DNA polymerases. The optimal concentration of

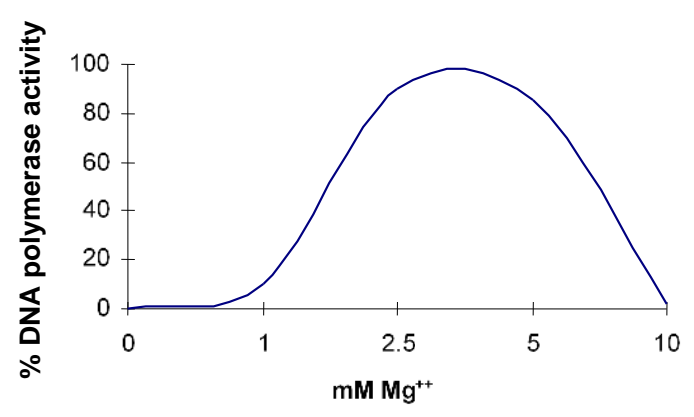

a)
$\mathrm{Mg}^{++}$as an activator of this DNA polymerase in the form of $\mathrm{MgCl}_{2}$ was $2.5 \mathrm{mM}$ (Graph 3a). The activity of DNA polymerases isolated from other species of genus Bacillus steadily increased from 5-30 $\mathrm{mM} \mathrm{Mg}^{++}$[16].

EDTA is a required component in all buffers and solutions during the isolation process of the protein with DNA polymerase activity, while ethanol is the final compound used during the isolation of DNA. Due to their undesired effects, EDTA and ethanol were tested as inhibitors of DNA polymerase activity. A concentration of $10 \mathrm{mM}$ EDTA and $10 \%$ ethanol completely inhibited the DNA polymerase activity (Graph $3 \mathrm{~b}$ and c).

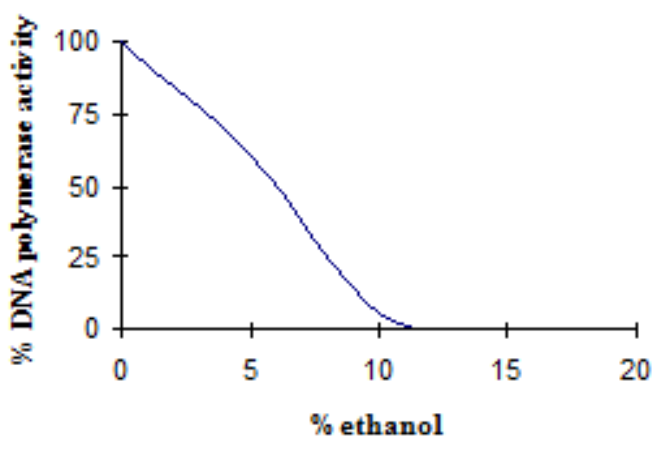

b)

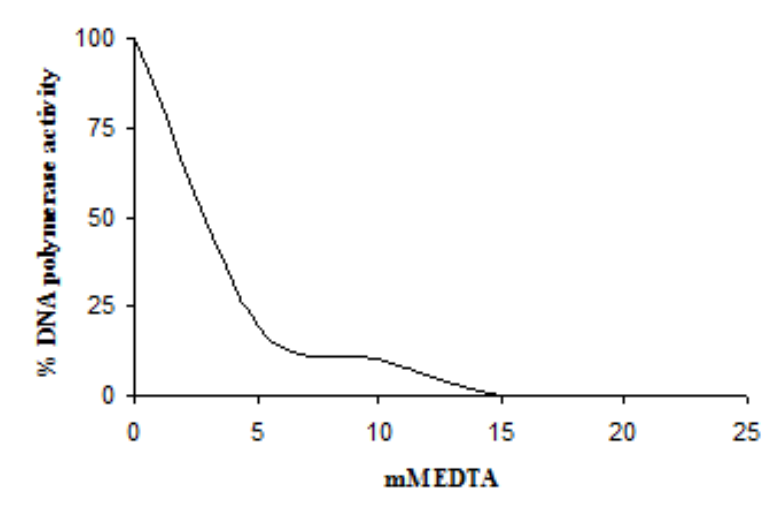

c)

Graph 3. DNA polymerase activity from Bacillus caldolyticus at different concentrations of:

a) $\mathrm{Mg}^{++}$as an activator, b) EDTA as an inhibitor; c) ethanol as an inhibitor (100\% activity equals to 5 Units/30 min.).

Critical concentrations of alcohols generally increased with the thermoresistance of the polymerases and decreased their activity. Comparison of various PCR conditions indicates that ethanol has specific mode of action by partial destabilization of the polymerase [15]. Lower concentrations of EDTA produced varying degrees of inhibition [12].

Acknowledgements. The authors would like to express their respect and gratitude to late acad. Georgi D. Efremov who was supporting this research.

\section{REFERENCES}

[1] P. Setlow, D. Brutlag, A. Kornberg, Deoxiribonucelic acid Polymerase: Two distinct enzymes in one polypeptide (I), J. Biol. Chem., 247, 224-231 (1972)

[2] V. Mizrahi, S. J. Benković, The dynamics of DNA polymerase - catalyzed reactions, J. Enzym.; 22, 437-457 (1980)

[3] R. E. Johnson, R. Klassen, L. Prakash, S. Prakash, A Major Role of DNA Polymerase $\delta$ in Replication of Both the Leading Lagging DNA Strands, Mol. Cell. 59 (2), 163-175 (2015).

DOI: 10.1016/j.molcel.2015.05.038 
[4] E. Boehm, K. Powers, C. Kondratick, M Spies, J. Houtman and M. Washington, The Proliferating Cell Nuclear Antigen (PCNA)-interacting Protein (PIP) Motif of DNA Polymerase $\eta$ Mediates Its Interaction with the CTerminal Domain of Rev1. J. Biol. Chem. 291 (16), 8735-8744 (2016). DOI: 10.1074/jbc.M115.697938

[5] K. Mulis, F. Faloona, Specific synthesis of DNA in vitro via a polymerase catalyzed chain reaction. Meth. Enzymol. 155, 335-350 (1987).

[6] A. Chien, D. Edgar, J. Trela, Deoxyribonucleic acid polymerase from extreme thermophile Thermus aquaticus. J. Bact.; 127, 1550-1557 (1976).

[7] A. Al Abedi, S. Arjunan, Molecular characterization of thermostable DNA polymerase of Bacillus stearothermophilus spp isolated from soil in Bangalore, Ind. Eur. J. Exper. Biol.; 4, 67-72 (2014).

[8] C. Elie, A. De Recondo, P. Forterre, Thermostable DNA polymerase from the archebacterium Sulfolobus acidocaldarius. Eur. J. Biochem, 178, 619-626 (1989).

[9] B. Dabrowska, S. Dabrowski, J. Kur, Purification and optimizing reaction conditions of DNA polymerase from Pyrococcus furiosus. 5-th Int. Stud. Sci. Conf. Gdańsk, Poland, 1997, Book of abstracts, p.15.

[10] F. Vigneault, R. Drouin, Optimal conditions and specific characteristics of Vent exo-DNA polymerase in ligation- mediated polymerase chain reaction protocols. Biochem. Cell Biol. 83 (2), 147-165 (2005).

[11] J. F. Huggett, T. Novak, J. A. Garson, C. Green, S. D. Morris-Jones, R. F. Miller, A. Zumla, Differential susceptibility of PCR reactions to inhibitors: an important and unrecognised phenomenon. BMC Res Notes. 2008; p. 70.

[12] E. J. Kontanis, F. A. Reed, Evaluation of real-time PCR amplification efficiencies to detect PCR inhibitors. $J$ Forensic Sci., 51, 795-804 (2006). DOI: $10.1111 /$ j.1556-4029.2006.00182.x

[13] Z. T. Popovski, G. D. Efremov, E. Emanuilova, E. Dokić-Trajkovska, Properties of thermophilic bacterial strain Bacillus caldolyticus isolated from hot spring Bansko, Macedonia, I Balk. Conf. Microbiol., Plovdiv, Bulgaria, 1999; Book of abstracts, p. 210.

[14] A. S. Kaledin, A. G. Slusarenko, S. I. Gorodeckï. Vydelenie I' svojstva DNK polymerazii iz ekstremnotermofilnoï bakterii Thermus aquaticus YT1. Biohim, 45, 644-651 (1980).

[15] S. Claveau, M. Sasseville, M. Beauregard, Alcoholmediated error-prone PCR. DNA Cell Biol., 23 (11), 789-95 (2004). DOI: 10.1089/dna.2004.23.789

[16] E. Sellmann, K. L. Schroder, I. M. Knoblich, P. Westermann, Purification and characterization of DNA polymerases from Bacillus species. J. Bacter; 174, (13) 4350-4355 (1992). 